\title{
HER2-positive advanced breast cancer: optimizing patient outcomes and opportunities for drug development
}

\author{
J C Singh ${ }^{1}, \mathrm{~K}$ Jhaveri $^{1}$ and F J Esteva ${ }^{*, 1}$ \\ ${ }^{1}$ Division of Hematology/Oncology, Laura and Isaac Perlmutter Cancer Center, New York University Langone Medical Center, 160 \\ East 34th Street, New York, NY 10016, USA
}

\begin{abstract}
Effective targeting of the human epidermal growth factor receptor 2 (HER2) has changed the natural history of HER2 overexpressing $(H E R 2+)$ metastatic breast cancer. The initial success of trastuzumab improving time to progression and survival rates led to the clinical development of pertuzumab, ado-trastuzumab emtansine and lapatinib. These biologic therapies represent significant additions to the breast medical oncology armamentarium. However, drug resistance ultimately develops and most tumours progress within 1 year. Ongoing studies are evaluating novel therapeutic approaches to overcome primary and secondary drug resistance in tumours, including inhibition of PI3K/TOR, HSP90, IGF-IR and angiogenesis. Mounting experimental data support the clinical testing of immune checkpoint modulators and vaccines. The central nervous system remains a sanctuary site for HER2 + breast cancer and further studies are needed for the prevention and treatment of brain metastases in this population. Despite efforts to identify predictors of preferential benefit from HER2-targeted therapies (e.g., truncated HER2, PTEN loss and SRC activation), HER2 protein overexpression and/or gene amplification remains the most important predictive factor of response to HER2-targeted therapies. In this article, we review the optimal sequence of HER2-targeted therapies and describe ongoing efforts to improve the outcome of HER2 + advanced breast cancer through rational drug development.
\end{abstract}

The discovery of the human epidermal growth factor receptor 2 (HER2) (King et al, 1985; Schechter et al, 1985), its association with poor prognosis in breast cancer (Slamon et al, 1987) and the potential of recombinant DNA technology to produce monoclonal antibodies generated great enthusiasm in academic laboratories and industries in the 1980s. The development of trastuzumab (herceptin, Genentech, South San Francisco, CA, USA) monoclonal antibody therapy represented a paradigm shift in oncology from non-specific chemotherapy to a molecularly targeted approach (Esteva, 2004). Trastuzumab binds domain IV of the extracellular component of the HER2 protein located close to the cell membrane, resulting in signal transduction blockade and prevention of HER2 cleavage (Figure 1). Addition of trastuzumab to conventional cytotoxic chemotherapy improved overall response rates (ORR), time to progression (TTP) and overall survival (OS) rates (Slamon et al, 2001). Lapatinib, a tyrosine kinase inhibitor of EGFR and HER2 was found to be effective in combination with capecitabine in patients whose metastatic tumours were progressing on trastuzumab-based chemotherapy (Geyer et al, 2006).
Pertuzumab (Perjeta, Genentech) is a humanised monoclonal antibody directed against domain II of the extracellular component of HER2, which is where receptor dimerisation occurs (Adams et al, 2006). The development of antibody-drug conjugates is an area of high interest in oncology drug development. Ado-trastuzumab-DM1 (T-DM1, Kadcyla) combines the HER2targeted antitumor properties of trastuzumab with the antimicrotubule agent DM1 (derived from maytansine) allowing preferential intracellular drug delivery to the HER2 + tumour cells. Trastuzumab, pertuzumab and T-DM1 can all induce antibody-dependent cellular cytotoxicity.

To date, HER2 remains to be the most important predictive factor of response to HER2-targeted therapies (Seidman et al, 2001). A tumour is considered HER $2+$ if the ratio of HER $2 /$ cep 17 is at least 2.0 or if the HER2 gene copy number is $>6$ (independently of chromosome 17) (Wolff et al, 2013).

Despite improvements in progression-free survival (PFS) and OS rates, HER2 + MBC remains an incurable disease and clinical research remains as important as ever. In this article we discuss the

*Correspondence: Professor FJ Esteva; E-mail: francisco.esteva@nyumc.org

Received 20 February 2014; revised 11 June 2014; accepted 16 June 2014; published online 15 July 2014 


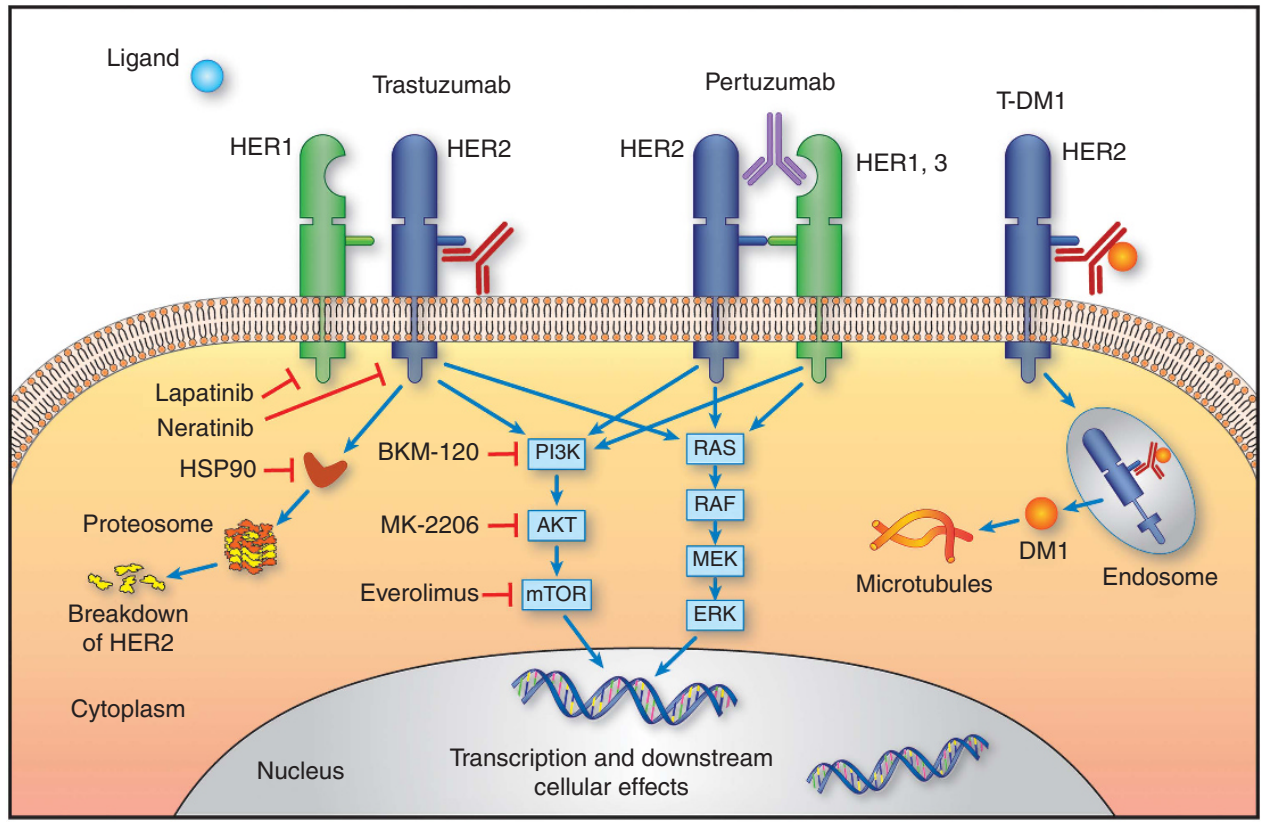

[Proliferation, survival, invasion, angiogenesis]

Figure 1. Molecular approaches to HER2 targeted therapy.

optimal sequencing of HER2-targeted therapies in HER2 + MBC based on line of therapy. We discuss potential predictive markers of resistance to HER2-targeted therapies and review ongoing efforts to incorporate novel drugs and drug combinations, including the promise of immunotherapy.

\section{OPTIMAL SEQUENCING OF ANTI-HER2 THERAPIES IN} $\mathrm{MBC}$

First-line therapy of HER2 + MBC. In the trastuzumab pivotal phase III trial, 469 women with HER2 + metastatic breast cancer were randomized to standard chemotherapy alone (doxorubicin or epirubicin in combination with cyclophosphamide) vs chemotherapy plus trastuzumab. The addition of trastuzumab to chemotherapy was associated with longer TTP (7.4 months vs 4.6 months, $P<0.001)$, a higher ORR (50\% vs $32 \%, P<0.001)$, a longer duration of response (9.1 months $v s 6.1$ months, $P<0.001$ ), a lower rate of death at 1 year $(22 \% v s 33 \%, P=0.008)$, a longer OS (25.1 months $v s 20.3$ months, $P=0.01)$ and a $20 \%$ reduction in the risk of mortality (Slamon et al, 2001). Based on this trial, trastuzumab was approved in combination with paclitaxel for first-line treatment of HER2 + MBC in 1998. Other combinations shown to be effective in this setting include docetaxel plus trastuzumab (Esteva et al, 2002; Marty et al, 2005) and vinorelbine plus trastuzumab (Burstein et al, 2007). Although efficacious, anthracycline/trastuzumab combinations are not indicated outside clinical trials in $\mathrm{MBC}$ due to increased risk of cardiac toxicity (Slamon et al, 2001).

Based on strong preclinical evidence that platinum and trastuzumab have synergistic activity, the three-drug combination of trastuzumab, carboplatin and docetaxel was tested in the Breast Cancer International Research Group 007 (BCIRG007) trial without showing improvement in PFS, OS or ORR when compared with trastuzumab-docetaxel combination (Valero et al, 2011). In a separate open-label, randomized study, addition of platinum to trastuzumab and paclitaxel improved PFS and ORR but not OS (Robert et al, 2006). Carboplatin adds toxicity with no clear improvement in clinical outcomes, and therefore is not considered standard of care for patients with HER2 + MBC.
To evaluate if trastuzumab plus chemotherapy was a superior strategy in metastatic disease compared with trastuzumab alone, Inoue et al (2011) completed a randomized study in which they compared two arms: trastuzumab $(\mathrm{H})$ alone followed by $\mathrm{H}+$ docetaxel (D) $(\mathrm{H} \rightarrow \mathrm{H}+\mathrm{D})$ upon progression $v s \mathrm{H}+\mathrm{D}$ combination therapy from the onset for HER2 + MBC. Both PFS and OS were significantly prolonged in the $\mathrm{H}+\mathrm{D}$ group. Based on the results of this trial, combination of trastuzumab with chemotherapeutic agent is considered a preferred first-line strategy compared with than trastuzumab alone (Inoue et al, 2011).

Preclinical studies showed that a combination of trastuzumab and pertuzumab can induce apoptosis in vitro (Nahta et al, 2004) and tumour regression in vivo (Lee-Hoeflich et al, 2008). The Clinical Evaluation of Pertuzumab and Trastuzumab (CLEOPATRA) trial was a large phase III randomized trial in which 808 patients with HER2 + MBC were randomized to trastuzumab plus docetaxel (TH) with or without pertuzumab in the first-line setting. The pertuzumab group showed significant improvement in PFS (18.5 months vs 12.4 months, 95\% confidence interval (CI): $0.51-0.75, P<0.001$ ) and OS rates (DeLong et al, 1988). Based on the results of this trial, FDA granted approval for the use of trastuzumab, pertuzumab and docetaxel combination as the firstline therapy in HER2 + MBC. This is currently the preferred first-line treatment for most patients with HER2 + MBC (Figure 2).

Hormone receptor positive and HER2 + MBC. About $50 \%$ of the HER $2+$ patients are also hormone receptor positive $(\mathrm{HR}+)$. There are important biological differences underlying pure HER2 + /hormone receptor negative $(\mathrm{HR}-)$ tumours and HER $2+/ \mathrm{HR}+$ tumours. When $\mathrm{HR}$ is overexpressed, the molecular profile of these tumours resembles the so-called luminal B subtype of breast cancer (Perou et al, 2000). Cross-talk between HER2 and HR leads to resistance to hormonal agents, and resistance can be partially overcome by anti-HER2 therapies. In the phase III Trastuzumab and Anastrozole Directed Against oestrogen receptor (ER)-Positive HER2-Positive Mammary Carcinoma (TAnDEM) trial, 207 postmenopausal women with HER2 + / $\mathrm{HR}+$ disease were assigned to anastrozole alone or with trastuzumab. The combination arm showed significant improvement in PFS (HR: 0.63, 95\% CI: 0.47-0.84, median: PFS 4.8 vs 2.4 months, $P=0.0016$ ) but not in the OS. However, there was a $70 \%$ 


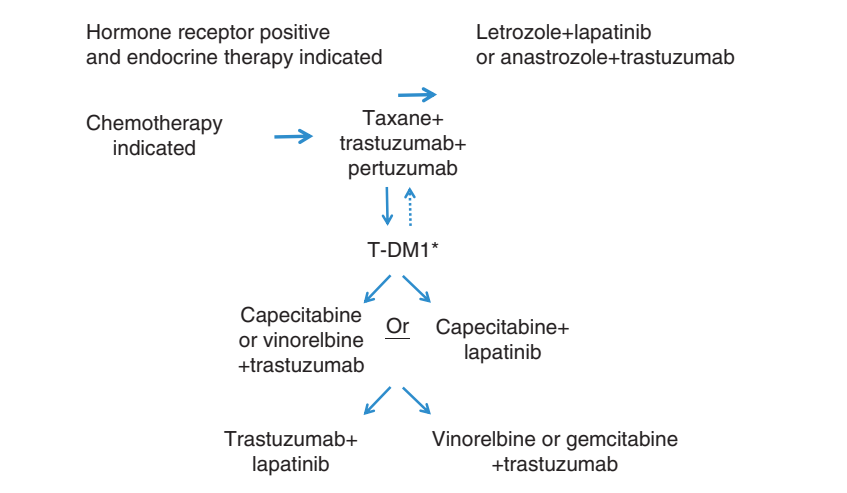

*T-DM1 may be used as front line if the patient develops metastasis within 6 months of finishing adjuvant chemotherapy.

Figure 2. Sequencing of targeted therapies in HER2-positive metastatic breast cancer.

cross-over rate to the combination arm in this study (Kaufman et al, 2009). Similarly, combination of letrozole with lapatinib was found to be more effective than letrozole alone in patients with HER2 + /HR + MBC (Johnston et al, 2009). It is an acceptable approach to start with a combination of an anti-oestrogen and an anti-HER2 therapy in the metastatic setting especially if the disease burden is limited without visceral crisis.

Clinical trials in the neoadjuvant setting have shown that HR status is a marker of sensitivity to anti-HER2-directed therapies, with higher pCR rates consistently observed in patients with HRnegative tumours. For example, in the NEO-SPHERE trial 553 patients with HER2 + breast cancer were randomized to one out of four neoadjuvant regimens prior to surgery as follows: $\mathrm{TH}$, pertuzumab plus trastuzumab and docetaxel (THP), pertuzumab plus trastuzumab (HP) or pertuzumab plus docetaxel (TP). Randomisation was stratified by breast cancer type 556 (operable, locally advanced or inflammatory) and ER or progesterone 557 receptor positivity. The $\mathrm{pCR}$ rates were significantly higher for HRnegative tumours compared with HR-positive in all four groups (TH 20\% HR + vs 37\% HR - ; THP 26\% HR + vs $63 \mathrm{HR}-$; HP $6 \%$ vs $27 \%$; TP $17 \%$ vs $30 \%$ ) (Gianni et al, 2012). Similar findings have been reported from the NEO-ALTTO (Baselga et al, 2012a) and GEPARQUINTO (Untch et al, 2012) trials. This has important implications on future trial design and sample size calculations. Ideally, clinical trials should focus on either HER $2+/ \mathrm{HR}-$ tumours or HER $2+/ \mathrm{HR}+$ tumours. If both tumour types are included, the sample size should be calculated separately for each subgroup.

Ongoing trials in first-line HER2 + MBC. Improving outcomes in the first-line setting is always important for patients with MBC, especially if survival rates are significantly improved. The MARIANNE trial is evaluating the role of first-line T-DM1 in HER2 + MBC. More than 1000 patients have been randomized to one of the three arms, taxane plus trastuzumab, T-DM1 alone or T-DM1 plus pertuzumab. Results of this trial are awaited with great interest because they may change clinical practice.

Second-line therapy and treatment of refractory HER2 + MBC. The FDA approved lapatinib for patients with HER2 + MBC who had received prior anthracycline and taxane-based chemotherapy and were progressing on trastuzumab-based therapy based on a phase III trial, comparing lapatinib/capecitabine combination with capecitabine alone. The addition of lapatinib to capecitabine was shown to prolong TTP (8.4 months vs 4.1 months, HR: 0.47, 95 CI: 0.33-0.67, P<0.001) (Geyer et al, 2006). This combination is now an accepted second-line approach for patients with HER2 + MBC who have progressed on prior trastuzumab containing regimen especially when T-DM1 is not available.
In the phase III EMILIA trial, 991 patients with HER2 + MBC who had previously been treated with trastuzumab and a taxane, were randomly assigned to T-DM1 or lapatinib/capecitabine combination. The T-DM1 group showed significant improvement in the median PFS (9.6 months vs 6.4 months, 95\% CI: $0.55-0.77$, $P<0.001)$, median OS (30.9 months vs 25.1 months, HR for death from any cause: $0.68,95 \%$ : CI $0.55-0.85, P<0.001)$ and $\mathrm{ORR}$ (43.6\% vs $30.8 \%, P<0.001)$ with a lower incidence of grade 3 toxicity (57\% vs 41\%) (Verma et al, 2012). Based on the results of the EMILIA trial, the FDA approved T-DM1 as a second-line agent in HER2 + MBC.

In a phase II trial, Krop et al (2012) reported significant activity for T-DM1 in patients with HER2 + MBC who had received prior anthracycline, taxanes capecitabine, trastuzumab and lapatinib therapy. The phase III TH3RESA trial randomized $\sim 600$ patients with advanced HER2-positive breast cancer, previously treated with at least two HER2-directed therapies (including trastuzumab and lapatinib) in a $2: 1$ ratio to T-DM1 or physician's choice of treatment (HER2-targeted regimens for $83.2 \%$ and single-agent chemotherapy for $16.8 \%$ ). In the initial results of this trial reported at the European Cancer Congress in September 2013, patients treated with T-DM1 had a significantly prolonged median PFS (6.2 months vs 3.3 months, HR: 0.528, 95\% CI: 0.422-0.661, $P<.0001)$. Therefore T-DM1 appears to be efficacious even in heavily pretreated patients who have not been exposed to T-DM1 as second-line therapy.

Combination of trastuzumab and pertuzumab has also demonstrated clinical efficacy in the second-line setting (Cortes et al, 2012). The combination of pertuzumab with trastuzumab is reasonable in patients who have not been exposed to first-line trastuzumab/pertuzumab/docetaxel as in CLEOPATRA trial.

Continuing trastuzumab beyond progression. Trastuzumab has demonstrated efficacy in heavily pretreated HER2 + MBC in combination with several other chemotherapeutic agents such as capecitabine, gemcitabine and vinorelbine. In a phase III randomized study, 156 patients with HER2 + MBC who had progressed on prior trastuzumab were randomized to capecitabine alone or capecitabine plus trastuzumab. The trastuzumab arm showed significant improvement in the TTP (5.6 months vs 8.2 months, HR: $0.69,95 \%$ CI: $0.48-0.97, P=0.0338)$ and ORR $(27 \%$ vs $48.1 \%$, Odds Ratio: $2.5, P=0.0115)$ but not OS (20.6 months vs 24.9 months, 95\% CI: 0.65-1.35, $P=0.73$ ) (von Minckwitz et al, 2009). This study was terminated prematurely because of the approval of lapatinib and capecitabine in this indication. Although it is not clear why patients would continue to benefit from continuation of trastuzumab in the setting of disease progression, it is possible that HER2 inhibition may continue to provide synergy with different chemotherapeutic agents administered sequentially.

Dual inhibition targeting both intracellular and extracellular domain of HER2 by combining lapatinib with trastuzumab has also been tested in metastatic HER2 + breast cancer. In the phase III EGF104900 trial, a heavily pretreated population which had progressed on prior trastuzumab-based regimens was randomly assigned to receive combination of lapatinib and trastuzumab or lapatinib monotherapy. In the final survival analysis, dual HER2 blockade led to significant 4.5-month improvement in OS (HR: 0.74, 95\% CI: $0.57-0.97, P=0.026$ ) in the $\mathrm{HR}+$ group (Blackwell et al, 2010).

MOLECULAR MECHANISMS OF RESISTANCE AND ONGOING CLINICAL TRIALS IN REFRACTORY HER2 + MBC

Human epidermal growth factor receptor 2 quantitative expression, either in terms of protein or mRNA levels within the clinically-defined HER2-positive tumours seems to predict higher 
or lower probability of response, as shown repeatedly from prespecified analyses of very influential prospective trials (e.g., CLEOPATRA, EMILIA, NEO-SPHERE, NEO-ALTTO and TRYPHAENA) (Baselga et al, 2012c; Gianni et al, 2012; Schneeweiss et al, 2013; Verma et al, 2012).

Hyperactivation of the PI3K pathway by activating mutations or loss of PTEN expression has been associated with resistance to trastuzumab-based chemotherapy (Esteva et al, 2010; Nagata et al, 2004). In a prospective study of patients who had been previously treated with trastuzumab and subsequently developed metastatic breast cancer, the metastatic tumours expressed lower levels of PTEN compared with primary tumours, suggesting that the PTEN loss may be a marker of trastuzumab resistance (Chandarlapaty et al, 2012). However, PTEN expression in primary breast cancer was not predictive of disease-free survival (DFS) or OS in adjuvant trastuzumab trials. Other proposed markers of trastuzumab resistance include a truncated form of HER2 (p95), PIK3CA mutations (Berns et al, 2007; Esteva et al, 2010), HER2/IGF-IR dimerisation (Nahta et al, 2005) and Src activation (Zhang et al, 2011). Although none of these markers have been validated in prospective clinical trials to exclude patients from HER2-directed therapies, molecular understanding provides target for rational drug development.

A multitude of clinical trials are assessing the safety and efficacy of novel treatments in patients with refractory HER2 + MBC (Table 1). In this section we will discuss selected novel approaches including those based on proposed mechanisms of resistance to HER2-targeted therapy (Figure 1).

\section{TYROSINE KINASE INHIBITORS}

Afatinib is an orally active irreversible dual inhibitor of EGFR and HER2 receptors. In a phase II study, afatinib monotherapy in heavily pretreated HER2 + MBC demonstrated partial response (PR) in 4 patients $(10 \%$ of 41$)$ and stable disease in 11 patients (37\%of 41) (Lin et al, 2012).

Neratinib is an orally active irreversible inhibitor of EGFR, HER2 and HER4 receptors. In a phase II open-label clinical trial, $240 \mathrm{mg}$ of oral neratinib was administered to trastuzumab pretreated $(n=66)$ and a trastuzumab naïve cohort $(n=70)$. The ORR was $24 \%$ and $56 \%$, respectively, and the most common grade 3 toxicity was diarrhoea.

\section{PI3K/Akt/mTOR PATHWAY INHIBITORS}

In preclinical models, mTOR inhibitors synergize with trastuzumab and have shown to cause complete regression of mouse HER2 + mammary tumours (Lu et al, 2007) In a phase I/II trial of trastuzumab combined with mTOR inhibitor everolimus for HER2 + MBC, PR was seen in 15\% patients and s.d. $>6$ months in 19\% (Morrow et al, 2011). BOLERO-3 was a phase III trial comparing vinorelbine and trastuzumab alone or in combination with everolimus in 569 patents with HER2 + MBC resistant to trastuzumab. The preliminary findings of this study show significant prolongation in TTP (5.8 months vs 7 months, HR: 0.78 ; 95\% CI: $0.65-0.95 ; P<0.01)$ in the everolimus arm. The data on OS, the secondary endpoint of this study is not yet mature. Exploratory analysis of biomarkers in the BOLERO-3 trial suggests that the addition of everolimus to trastuzumab plus vinorelbine for HER2-positive advanced breast cancer may be most beneficial in patients with low PTEN or high pS6 levels (Jerusalem et al, 2013). No clear benefit of everolimus was observed in patients with normal PTEN or low pS6 levels. These data support the hypothesis that low PTEN expression is a marker of trastuzumab resistance
(Nagata et al, 2004; Esteva et al, 2010). Subset analyses showed a larger benefit for the everolimus group in HER2 + /HR - tumours, compared with HER $2+/ \mathrm{HR}+$ tumours. This seems counterintuitive in view of the results of everolimus and exemestane in $\mathrm{HR}+$ tumours (BOLERO-2) (Baselga et al, 2012b). No treatmentbiomarker interaction was reported between everolimus and PI3K mutations. Data from the Cancer Genome Atlas (TCGA-Network, 2012) suggest that despite a similar incidence of PI3K mutation in HER2 enriched and luminal tumours, markers of pathway activations were differently expressed in these two subtypes in the presence of PI3K mutations.

Several PI3 kinase inhibitors are under phase $1 / 2$ stage of development. A phase 1/2 study of SAR245408 (S08) in combination with trastuzumab or paclitaxel and trastuzumab in patients with HER2 + MBC, who progressed on a previous trastuzumabbased regimen, has been completed. Other PI3 kinase inhibitors (e.g., BKM120 (NCT01589861)) are also under investigation.

\section{HEAT SHOCK PROTEIN 90 (HSP90) INHIBITORS}

Proteosomal degradation of oncoproteins such as HER2 is caused by compounds called HSP90 inhibitors. Moreover, p-95HER2, which is a truncated form of HER2 and also a major mechanism of trastuzumab resistance has been shown to undergo degradation by HSP90 inhibitors. Tanespimycin has been evaluated in HER2 + MBC that had previously progressed trastuzumab in the phase II setting. The ORR was $22 \%$, the clinical benefit rate (ORR and SD for at least 6 months) was 59\% and median PFS was 6 months (95\% CI: 4-9 months). Another HSP90 inhibitor, ganetespib (STA9090), was tested as monotherapy in a phase II setting (Jhaveri et al, 2014). While the study did not meet the primary endpoint of ORR in the first stage of the Simon-2 stage design, modest activity was noted in heavily pretreated, trastuzumab-refractory patients. Based on the preclinical data that shows synergistic activity for combining HSP90 inhibitors with taxanes, we are now conducting a phase I trial of ganetespib plus paclitaxel plus trastuzumab in trastuzumab refractory, HER2 + MBC (NCT02060253).

\section{OTHER TARGETED STRATEGIES}

KD019 is a small molecule that simultaneously blocks the tyrosine kinase of EGFR, HER2, Src and the vascular endothelial growth factor receptor 2 (VEGFR2), all of which are implicated in the processes of tumour cell growth, angiogenesis and metastases. A phase I study of KD019 plus trastuzumab in HER2 overexpressed or amplified MBC is ongoing for patients who have received two or more prior anti-HER2-directed therapies (Jhaveri et al (2014), Perlmutter Cancer Center at NYU Langone).

It has been demonstrated that cross-talk between IGF-1R and HER2 as well as IGF mediated phosphorylation of HER2 results in trastuzumab resistance (Nahta et al, 2005, 2006), providing merit to exploring IGF-1R inhibitors such as Cixotumumab in clinical trials. Preclinical studies have shown upregulation of VEGF in HER2 overexpressed breast cancers, and the phase 2 study of trastuzumab and bevacizumab combination in HER2 + MBC was promising. However, bevacizumab, a monoclonal antibody against VEGF-A receptor, failed to improve PFS when combined with trastuzumab and docetaxel in a phase 3 trial compared with the non-bevacizumab arm (Gianni et al, 2013).

One of the mechanisms of action of trastuzumab is thought to be induction of ADCC. It has been demonstrated that higher percentage of tumour infiltrating lymphocytes is associated with better response to trastuzumab in both adjuvant (Loi et al, 2013) and neoadjuvant setting. In correlative preclinical studies, higher 
Table 1. Ongoing clinical trials in HER2-positive metastatic breast cancer

\begin{tabular}{|c|c|c|c|c|}
\hline Ongoing trial & Sample size & Trial design & Primary end point & Comments \\
\hline \multicolumn{5}{|l|}{ Lapatinib } \\
\hline NCT01526369 & 600 & $\begin{array}{l}\text { TH } \\
\text { THL }\end{array}$ & PFS & $\begin{array}{l}\text { Phase 3, comparison of single vs } \\
\text { dual HER2 inhibition in first-line } \\
\text { setting }\end{array}$ \\
\hline NCT00968968 & 280 & $\begin{array}{l}\text { Lapatinib + trastuzumab } \\
\text { Trastuzumab }\end{array}$ & 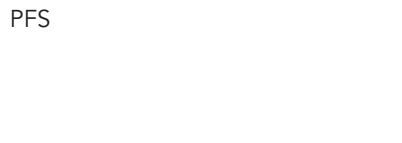 & $\begin{array}{l}\text { Phase 3, continued HER2 } \\
\text { suppression therapy after } \\
\text { completion of first- or second-line } \\
\text { trastuzumab plus chemotherapy }\end{array}$ \\
\hline DETECT III & 228 & $\begin{array}{l}\text { Standard chemo or endocrine therapy } \\
\text { Standard chemo or endocrine } \\
\text { therapy + lapatinib }\end{array}$ & PFS & $\begin{array}{l}\text { Phase 3, patients with initially } \\
\text { HER2-negative metastatic breast } \\
\text { cancer and HER2-positive } \\
\text { circulating tumour cells }\end{array}$ \\
\hline NCT00496366 & 11 & Capecitabine + lapatinib & RR & Phase 2, first line \\
\hline NCT01622868 & 143 & $\begin{array}{l}\text { Whole brain radiotherapy } \\
\text { Whole brain radiotherapy + lapatinib }\end{array}$ & $\mathrm{CR}$ rate in the brain & $\begin{array}{l}\text { Phase } 2 \text { randomized study of in- } \\
\text { patients with brain metastasis }\end{array}$ \\
\hline \multicolumn{5}{|l|}{ Pertuzumab } \\
\hline PHEREXA & 450 & $\begin{array}{l}\mathrm{XH} \\
\mathrm{XH}+\text { pertuzumab }\end{array}$ & PFS & $\begin{array}{l}\text { Efficacy of pertuzumab in second- } \\
\text { line setting after progression on } \\
\text { trastuzumab. }\end{array}$ \\
\hline NCT01306942 & 48 & Dasatinib + trastuzumab + paclitaxel & DLT, ORR & Phase I/II study \\
\hline PERUSE & 1500 & Pertuzumab + trastuzumab + taxane & Safety: incidence of adverse events & $\begin{array}{l}\text { Multicenter, open-label, single- } \\
\text { arm study in first line }\end{array}$ \\
\hline NCT01491737 & 250 & $\begin{array}{l}\text { Pertuzumab + trastuzumab + aromatase } \\
\text { inhibitor } \\
\text { Trastuzumab + aromatase inhibitor + induction } \\
\text { chemotherapy }\end{array}$ & PFS & $\begin{array}{l}\text { Randomized, multicenter phase } 2 \\
\text { trial, first-line patients with HER2 } \\
\text { positive and hormone receptor } \\
\text { positive }\end{array}$ \\
\hline NCT01565083 & 210 & Pertuzumab + trastuzumab + vinorelbine & ORR & $\begin{array}{l}\text { Two-cohort, open-label, } \\
\text { multicenter phase } 2 \text { trial, first line }\end{array}$ \\
\hline NCT01276041 & 69 & Paclitaxel + trastuzumab + pertuzumab & PFS at 6 months & $\begin{array}{l}\text { Phase } 2,0-1 \text { prior regimens for } \\
\text { metastatic disease allowed }\end{array}$ \\
\hline NCT01912963 & 68 & Eribulin mesylate + trastuzumab + pertuzumab & Adverse effect profile, ORR & Phase 2 \\
\hline \multicolumn{5}{|l|}{ T-DMI } \\
\hline TH3RESA & 605 & $\begin{array}{l}\text { Trastuzumab emtansine } \\
\text { Treatment of physician's choice }\end{array}$ & PFS, OS & $\begin{array}{l}\text { Phase } 3 \text { randomized, multicenter } \\
\text { trial; patients who have received } \\
\text { at least two prior regimens of } \\
\text { HER2-directed therapy }\end{array}$ \\
\hline NCT01702571 & 2000 & T-DM1 & Toxicity profile & Phase 3 , single arm, second line \\
\hline MARIANNE & 1095 & $\begin{array}{l}\text { Trastuzumab + taxane } \\
\text { Trastuzumab emtansine + pertuzumab } \\
\text { Trastuzumab emtansine + pertuzumab placebo }\end{array}$ & PFS & Phase 3 , randomized, multicenter \\
\hline NCT00077376 & 61 & Trastuzumab + ixabepilone + carboplatin & $\mathrm{RR}$ & Phase 2 \\
\hline
\end{tabular}

\section{$\mathrm{PI3K} / \mathrm{AKT} / \mathrm{mTOR}$ pathway inhibitors}

\begin{tabular}{|c|c|c|c|c|}
\hline NCT01283789 & 45 & Lapatinib + RAD-001 & 6 month ORR & $\begin{array}{l}\text { Phase } 2 \text { study to assess efficacy of } \\
\text { the combination in } \mathrm{MBC} \text { who } \\
\text { have progressed on trastuzumab } \\
\text { and/or lapatinib based therapies }\end{array}$ \\
\hline NCT01783756 & 47 & $\begin{array}{l}\text { Lapatinib + everolimus + capecitabine in } \\
\text { patients with CNS progression after } \\
\text { trastuzumab }\end{array}$ & CNS ORR & Phase $1 \mathrm{~b} / 2$ single-arm trial \\
\hline BOLERO-1 & 719 & $\begin{array}{l}\text { Everolimus + trastuzumab + paclitaxel } \\
\text { Trastuzumab + paclitaxel }\end{array}$ & PFS & $\begin{array}{l}\text { Randomized phase } 3 \text {, double- } \\
\text { blind, placebo-controlled } \\
\text { multicenter trial of first-line } \\
\text { therapy }\end{array}$ \\
\hline BOLERO-3 & 570 & $\begin{array}{l}\text { Everolimus + trastuzumab + vinorelbine } \\
\text { Trastuzumab + vinorelbine }\end{array}$ & PFS & $\begin{array}{l}\text { Randomized phase } 3 \text {, double- } \\
\text { blind, placebo-controlled } \\
\text { multicenter trial, pretreated }\end{array}$ \\
\hline
\end{tabular}




\section{Table 1. (Continued)}

\begin{tabular}{|c|c|c|c|}
\hline Ongoing trial & Sample size & Trial design & Primary end point \\
\hline \multicolumn{4}{|c|}{ PI3 kinase inhibitors } \\
\hline $\begin{array}{l}\text { NCT01589861 } \\
\text { NCT01471847 }\end{array}$ & $\begin{array}{c}106 \\
\text { Phase I: } 5\end{array}$ & $\begin{array}{l}\text { BKM120 + lapatinib } \\
\text { BEZ235 + trastuzumab (phase I/phase II) } \\
\text { Lapatinib + capecitabine (phase II) }\end{array}$ & $\begin{array}{l}\text { Phase Ib: MTD } \\
\text { Phase II: efficacy } \\
\text { DLT, PFS }\end{array}$ \\
\hline \multicolumn{4}{|l|}{ AKT Inhibitor } \\
\hline NCT01277757 & 40 & MK2206 & $\begin{array}{l}\text { Primary: response rate } \\
\text { Secondary: } \\
\text { progression-free survival }\end{array}$ \\
\hline NCT01245205 & 52 & MK2206 plus lapatinib & $\begin{array}{l}\text { Primary: } \\
\text { MTD, adverse reactions of the } \\
\text { combination } \\
\text { Secondary: } \\
\text { RR, DLT, safety of the combination, } \\
\text { PFS, mechanism of lapatinib } \\
\text { resistance }\end{array}$ \\
\hline NCT00567879 & 67 & Panobinostat and trastuzumab & $\begin{array}{l}\text { Dose determination and } \\
\text { preliminary anti-tumour activity }\end{array}$ \\
\hline
\end{tabular}

Comments

Tyrosine kinase receptor inhibitors (afatinib and neratinib)

\begin{tabular}{|c|c|c|c|c|}
\hline LUX-breast 1 & 508 & $\begin{array}{l}\text { Afatinib + vinorelbine } \\
\text { Trastuzumab + vinorelbine }\end{array}$ & PFS & $\begin{array}{l}\text { Phase } 3 \text {, patients progressing } \\
\text { after one prior trastuzumab } \\
\text { treatment }\end{array}$ \\
\hline LUX-breast 3 & 120 & $\begin{array}{l}\text { Afatinib } \\
\text { Afatinib + vinorelbine } \\
\text { Investigator's choice of regimen }\end{array}$ & $\begin{array}{l}\text { Patient benefit at } 12 \text { weeks defined } \\
\text { as absence of CNS or extra CNS } \\
\text { progression }\end{array}$ & $\begin{array}{l}\text { Phase } 2, \text { HER2 positive with } \\
\text { progressive brain metastases } \\
\text { after trastuzumab and/or lapatinib } \\
\text { based therapy }\end{array}$ \\
\hline $\begin{array}{l}\text { NCT00915018/ } \\
\text { NEFERTT }\end{array}$ & 480 & $\begin{array}{l}\text { Neratinib + paclitaxel } \\
\text { Trastuzumab + paclitaxel }\end{array}$ & PFS & Randomized phase 2, first line \\
\hline NCT00777101 & 233 & $\begin{array}{l}\text { Neratinib } \\
\text { Lapatinib + capecitabine }\end{array}$ & PFS & Randomized phase 2 \\
\hline NCT01494662 & 45 & Neratinib & ORR & Brain metastases \\
\hline
\end{tabular}

IGF-1R Inhibitor

\begin{tabular}{|l|l|l|l|l|}
\hline NCT00684983 & 154 & $\begin{array}{l}\text { Capecitabine + lapatinib } \\
\text { Capecitabine + lapatinib + IMC-A12 } \\
\text { (cixutumumab) }\end{array}$ & $\begin{array}{l}\text { Randomized phase 2, Previously } \\
\text { Treated With trastuzumab and an } \\
\text { anthracycline and/or a taxane }\end{array}$ \\
\hline
\end{tabular}

\section{Bevacizumab}

\begin{tabular}{|l|l|l|l|}
\hline NCT00520975 & 489 & $\begin{array}{l}\text { First-line chemotherapy (carboplatin and } \\
\text { paclitaxel) + trastuzumab } \\
\text { First-line chemotherapy (carboplatin and } \\
\text { paclitaxel) + trastuzumab + bevacizumab }\end{array}$ & PFS \\
\hline
\end{tabular}

PFS

ORR

\begin{tabular}{|l|l|l|}
\hline NCT01677455 & 70 & Ganetespib (STA-9090) \\
NCT02060253 & 18 & $\begin{array}{l}\text { Ganetespib plus paclitaxel plus trastuzumab } \\
\text { trial }\end{array}$
\end{tabular}

Primary: MTD

Secondary: to evaluate the possible effects of ganetespib on the PK of paclitaxel; efficacy of the combination ORR, PFS, duration of response and clinical benefit rate (complete response + partial response + stable disease $>24$ weeks).
Randomized phase III doubleblind placebo-controlled trial
Phase II, patients with advanced breast cancer who have tumours with a PIK3CA mutation, or an AKT mutation, and/or PTEN Loss/ PTEN mutation

Phase I, refractory solid tumours followed by dose expansion in advanced HER2 + breast cancer

Phase 1, explore preliminary antitumour activity of the combination
Phase Ib/II, patients with HER2positive locally advanced or metastatic breast cancer who failed prior to trastuzumab 


\section{Table 1. (Continued)}

\begin{tabular}{|c|c|c|c|c|}
\hline Ongoing trial & Sample size & Trial design & Primary end point & Comments \\
\hline \multicolumn{5}{|l|}{ Miscellaneous } \\
\hline $\begin{array}{l}\text { NCT01269346 } \\
\text { NCT01413828 }\end{array}$ & 52 & $\begin{array}{l}\text { Eribulin mesylate }+ \text { trastuzumab } \\
\text { Concurrent trastuzumab }+ \text { anthracycline } \\
\text { Sequential trastuzumab, anthracycline }\end{array}$ & $\begin{array}{l}\text { ORR } \\
\text { Cardiotoxicitiy (heart failure rate at } \\
2 \text { years) }\end{array}$ & $\begin{array}{l}\text { Phase 2, multicenter, single-arm } \\
\text { study, first-line }\end{array}$ \\
\hline \multicolumn{5}{|c|}{ Peptide vaccines } \\
\hline $\begin{array}{l}\text { NCT00343109 } \\
\text { NCT00791037 }\end{array}$ & $\begin{array}{l}38 \\
20\end{array}$ & $\begin{array}{l}\text { HER2/neu intracellular domain peptide-based } \\
\text { vaccine + GM-CSF } \\
\text { Adoptive T-Cell Therapy following in vivo } \\
\text { priming with a HER2/Neu (HER2) ICD peptide- } \\
\text { based vaccine }\end{array}$ & $\begin{array}{l}\text { Primary: relapse-free survival } \\
\text { Secondary: safety } \\
\text { Primary: safety and systemic toxicity } \\
\text { secondary: (a) proportion of } \\
\text { patients whose T cells persist at a } \\
\text { level that is same or greater as the } \\
\text { level after the final T-cell infusion } \\
\text { and subsequent booster } \\
\text { immunisations as assessed by IFN- } \\
\text { gamma } \\
\text { (b) development of CD4 + and } \\
\text { CD8 + epitope spreading } \\
\text { (c) response of skeletal or bone- } \\
\text { only disease by FDG-PET }\end{array}$ & $\begin{array}{l}\text { Phase } 2 \\
\text { Phase } 1 / 2\end{array}$ \\
\hline NCT01355393 & 98 & $\begin{array}{l}\text { Stage I (HER2/neu peptide vaccine and } \\
\text { rintatolimod) } \\
\text { Stage II, Arm I (HER2/neu peptide vaccine and } \\
\text { sargramostim) } \\
\text { Stage II, Arm II (HER2 vaccine, sargramostim } \\
\text { and rintatolimod) }\end{array}$ & $\begin{array}{l}\text { To choose the most promising ( } \\
\text { MBD) rintatolimod as an adjuvant } \\
\text { with HER2 vaccination, with respect } \\
\text { to toxicity and incidence and } \\
\text { magnitude of immune response. } \\
\text { Stage II: to determine if } \\
\text { rintatolimod, when given with GM- } \\
\text { CSF as a combined adjuvant } \\
\text { strategy with HER2 vaccination } \\
\text { increases both the incidence and } \\
\text { magnitude of HER2 Th1 immunity } \\
\text { as compared with the standard } \\
\text { GM-CSF adjuvant strategy. }\end{array}$ & $\begin{array}{l}\text { Phase } 1 / 2 \\
\text { Stage IV HER } 2+\text { breast cancer } \\
\text { patients enroled in this study } \\
\text { should have been treated } \\
\text { optimally with no evidence of } \\
\text { disease, or stable bone disease } \\
\text { only } \\
\text { Rintatolimod is an } \\
\text { immunomodulatory dsRNA drug } \\
\text { that binds to TLR-3 }\end{array}$ \\
\hline NCT01729884 & 20 & $\begin{array}{l}\text { HER2 Peptide-based vaccination monthly for } 3 \\
\text { months }\end{array}$ & $\begin{array}{l}\text { Primary: evaluate the development } \\
\text { of HER2/Neu (HER2)-specific } \\
\text { memory T Cells } \\
\text { Secondary: adverse effects }\end{array}$ & Phase II \\
\hline \multicolumn{5}{|c|}{ Dendritic cell vaccine } \\
\hline NCT01730118 & 65 & $\begin{array}{l}\text { Adenoviral transduced autologous dendritic cell } \\
\text { vaccine expressing human HER2/Neu ECTM in } \\
\text { adults with tumours with } 1-3+\mathrm{HER} 2 / \mathrm{Neu} \\
\text { expression }\end{array}$ & $\begin{array}{l}\text { Primary: (a) safety and toxicity } \\
\text { (b) determine immunogenicity } \\
\text { Secondary: determine the impact } \\
\text { of autologous AdHER2 dendritic } \\
\text { cell vaccination on tumour growth } \\
\text { rate and regression rate constants, } \\
\text { disease status by irRC, vaccine- } \\
\text { induced antibody profiles and other } \\
\text { immune assays. }\end{array}$ & $\begin{array}{l}\text { Phase } 1 \\
\text { Recurrent or progressive, } \\
\text { metastatic solid tumours } \\
\text { characterised by some HER2/neu } \\
\text { expression that have failed } \\
\text { standard therapies }\end{array}$ \\
\hline \multicolumn{5}{|c|}{ Whole tumour vaccines } \\
\hline NCT00095862 & 24 & Whole cells from the SVBR-1-GM cell line & $\begin{array}{l}\text { Primary: evaluate the safety, RR, } \\
\text { TTP, survival }\end{array}$ & $\begin{array}{l}\text { Phase } 1 / 2 \text { study vaccine using } \\
\text { whole cells from the SVBR-1-GM } \\
\text { cell line genetically engineered to } \\
\text { produce granulocyte- } \\
\text { macrophage colony stimulating } \\
\text { factor }\end{array}$ \\
\hline \multicolumn{5}{|c|}{ DNA Based vaccines } \\
\hline NCT01526473 & 12 & $\begin{array}{l}\text { AVX901 intramuscularly, given every } 2 \text { weeks } \\
\text { for a total of three doses. }\end{array}$ & $\begin{array}{l}\text { To evaluate the antitumor activity } \\
\text { and safety }\end{array}$ & $\begin{array}{l}\text { Phase } 1 \\
\text { AVX901 is an } \\
\text { alphaviral vector encoding The } \\
\text { HER2 extracellular domain and } \\
\text { transmembrane region }\end{array}$ \\
\hline
\end{tabular}


Table 1. (Continued)

\begin{tabular}{|c|c|c|c|c|}
\hline Ongoing trial & Sample size & Trial design & Primary end point & Comments \\
\hline \multicolumn{5}{|c|}{ Combining active and passive immunotherapy } \\
\hline NCT01922921 & 30 & $\begin{array}{l}\text { Study of HER2 ICD peptide-based } \\
\text { vaccine + trastuzumab + placebo } \\
\text { HER2 ICD peptide-based } \\
\text { vaccine + trastuzumab + polysaccharide-K }\end{array}$ & $\begin{array}{l}\text { Primary: toxicity } \\
\text { Secondary: induction of IFN- } \\
\text { gamma production and CD107a } \\
\text { expression in NK cells }\end{array}$ & $\begin{array}{l}\text { Phase } \mathrm{I} / \mathrm{II} \text { randomized not yet } \\
\text { recruiting }\end{array}$ \\
\hline NCT00399529 & 22 & $\begin{array}{l}\text { Combination therapy with trastuzumab, } \\
\text { cyclophosphamide, and an allogeneic GM-CSF- } \\
\text { secreting breast tumour vaccine }\end{array}$ & $\begin{array}{l}\text { Primary: safety, clinical benefit } \\
\text { Secondary: immunological } \\
\text { response }\end{array}$ & $\begin{array}{l}\text { Phase 2: vaccine containing a } \\
\text { mixture of two GM-CSF-secreting } \\
\text { allogeneic breast cancer cell lines }\end{array}$ \\
\hline NCT00847171 & 20 & $\begin{array}{l}\text { Trastuzumab + cyclophosphamide + allogeneic } \\
\text { GM-CSF-secreting breast tumour vaccine }\end{array}$ & $\begin{array}{l}\text { Primary: safety, immunological } \\
\text { response } \\
\text { Secondary: progression-free } \\
\text { survival }\end{array}$ & $\begin{array}{l}\text { Phase } 2 \\
\text { In metastatic HER2/Neu- } \\
\text { overexpressing breast cancer with } \\
\text { no evidence of disease }\end{array}$ \\
\hline NCT00266110 & 26 & $\begin{array}{l}\text { Multiepitope dendritic cell } \\
\text { vaccine + trastuzumab + vinorelbine ditartrate }\end{array}$ & $\begin{array}{l}\text { Primary: efficacy } \\
\text { Secondary: determine if this } \\
\text { regimen is effective in generating } \\
\text { functional antigen-specific } T \text { cells }\end{array}$ & $\begin{array}{l}\text { Metastatic HER2-positive breast } \\
\text { cancer expressing HLA-A0201 }\end{array}$ \\
\hline \multicolumn{5}{|c|}{ 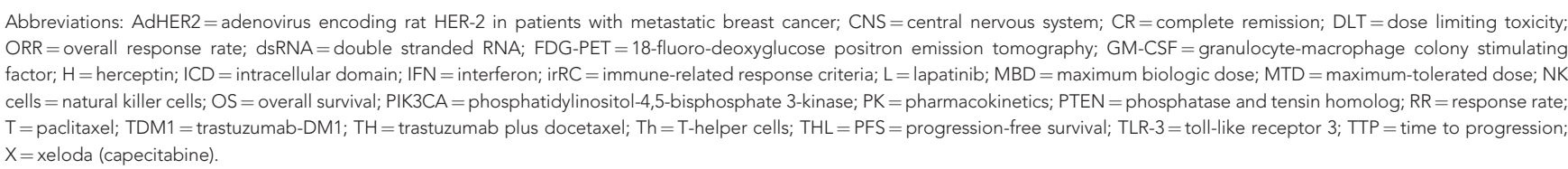 } \\
\hline
\end{tabular}

PD-1 (programmed death-1), a T-cell checkpoint ligand expression, was associated with greater trastuzumab benefit. The negative regulator of $\mathrm{T}$-cell mediated immune response is $\mathrm{PD}-1$, so antibodies blocking PD-1 and its ligand PD-L1 enhance the T-cell mediated immune response. Trastuzumab may modulate tumour microenvironment by inhibiting tumour-mediated immunosuppression via factors like PD-1 (Stagg et al, 2011). Combining trastuzumab with anti-PD-1 and anti-PD-L1 antibodies showed greater tumour regression in mouse models of HER $2+$ mammary tumours. Therefore, there seems to be merit in exploring the impact of combining trastuzumab with inhibitors of negative T-cell regulation, such as anti-CTLA4 antibody, anti-PD-1 or anti-PDL-1, in HER2 + MBC.

The HER2 has been explored as an antigen for vaccine development in HER2 + breast cancer (Table 2). One peptidebased vaccine that merits special mention is the E75 vaccine derived from the extracellular domain of HER2 receptor. When compared with the unvaccinated arm, E75 was found to decrease recurrence rates when administered in the adjuvant setting for node positive HER2 + breast cancer (DFS rates at 22 months: 85.7\% vs 59.8\%) (Peoples et al, 2005).

\section{BRAIN METASTASES (BM)}

The incidence of BM in patients with HER2 + MBC increases over time and may be attributable partly to marked reduction in mortality as a result of HER2 inhibition and control of non-CNS metastatic progression and monoclonal antibodies' inability to cross the blood brain barrier (BBB). Central nervous system involvement and its treatment remains one of the biggest challenges in HER2 + MBC. Current research is focused on various approaches including use of small molecule inhibitors that have the potential to cross the $\mathrm{BBB}$ (for e.g. Afatinib and everolimus), using molecules concurrently with radiation, and lastly utilising immunotherapy before and after radiotherapy based on the efficacy noted in melanoma patients with BM. In addition in the phase 2 LANDSCAPE study, 45 patients with untreated HER2 + BM received lapatinib and capecitabine in combination.
After a median follow-up of 21.2 months, $66 \%$ of patients achieved a PR. The incidence of grade 3 or 4 adverse events was $49 \%$. This study suggests that capecitabine and lapatinib combination may be an acceptable first-line regimen in the management of BM in HER2 + MBC (Bachelot et al, 2013). However, this regimen is yet to be compared with other treatment modalities such as whole brain radiation in a larger phase 3 trial.

\section{CONCLUSIONS}

Human epidermal growth factor receptor 2 is a validated therapeutic target that remains relevant throughout the disease process. Patients with HER $2+\mathrm{MBC}$ can be treated safely with a variety of systemic therapies and survival rates are improving. The landscape of anti-HER2 therapy is changing very quickly. In 2012, pertuzumab, a humanised monoclonal antibody against HER2, was approved for first-line therapy of HER2 + MBC in combination with trastuzumab and docetaxel. In 2013, the antibody-drug conjugate T-DM1 was approved in the second-line setting, displacing lapatinib/capecitabine. The MARIANNE trial is evaluating the role of T-DM1 as front-line therapy and this study may change practice. Dual HER2 inhibition with trastuzumab and pertuzumab, trastuzumab and lapatinib or pertuzumab and T-DM1 is here to stay in the metastatic setting. In fact, in an attempt to improve disease-free and OS rates, pertuzumab and T-DM1 are now being evaluated in the neoadjuvant and adjuvant settings (Jhaveri and Esteva, 2014). How to use these agents after patients are exposed to them in the adjuvant setting is not known, but efficacy is likely to be lower than what has been reported to date (Murthy et al, 2014). In addition to specific targeted therapies, patients with HER2 + MBC are treated with chemotherapy (e.g., taxanes, capecitabine, vinorelbine, gemcitabine and platinum salts) and endocrine therapy. With so many treatment options available, it is increasingly important to develop evidence-based guidelines for the initial and subsequent treatment of HER2 + MBC. Furthermore, clinical trials should take into consideration the optimal sequence of HER2 targeted therapies in patients with $\mathrm{HR}+$ and $\mathrm{HR}-\mathrm{HER} 2+\mathrm{MBC}$. Understanding mechanisms of 
Table 2. Vaccine types available for HER2 overexpressing breast cancer

\begin{tabular}{|c|c|c|c|}
\hline Vaccine type & Mechanism & Advantages & Limitations \\
\hline Peptide based & $\begin{array}{l}\text { Aim at inducing immune responses using antigen } \\
\text { epitopes derived from tumour-associated antigens. }\end{array}$ & $\begin{array}{l}\text { HER2 specific T-cell immunity including intramolecular } \\
\text { ES within the HER2 protein domain persists years after } \\
\text { immunization. ES is a significant predictor of improved } \\
\text { overall survival(Salazar et al, 2009) } \\
\text { Specific monitoring of immune response is possible. }\end{array}$ & $\begin{array}{l}\text { Immune response } \\
\text { limited to one or few } \\
\text { epitopes } \\
\text { Require an adjuvant to } \\
\text { generate immunological } \\
\text { response } \\
\text { Require HLA restriction } \\
\text { Stimulate CTLs, so } \\
\text { unable to generate } \\
\text { sustained immunological } \\
\text { memory }\end{array}$ \\
\hline Protein based & Consist of entire or truncated form of HER2 protein & $\begin{array}{l}\text { Not HLA restricted } \\
\text { Elicit CD4 T-cell response }\end{array}$ & $\begin{array}{l}\text { Less efficient sensitising } \\
\text { of CTLs }\end{array}$ \\
\hline DNA based & $\begin{array}{l}\text { DNA delivered along with the vector (e.g., viral vector) } \\
\text { to the antigen presenting cells leading to in vivo } \\
\text { transcription and translation of DNA of interest into } \\
\text { protein }\end{array}$ & $\begin{array}{l}\text { No HLA restriction } \\
\text { Cost-effective and easy to develop }\end{array}$ & $\begin{array}{l}\text { Risk of abnormal } \\
\text { processing of bacterial } \\
\text { and viral vectors }\end{array}$ \\
\hline $\begin{array}{l}\text { Dendritic cell } \\
\text { vaccines }\end{array}$ & $\begin{array}{l}\text { Dendritic cells are potent antigen presenting cells } \\
\text { which can be transfected with HER2 protein containing } \\
\text { vectors and injected back to generate in-vivo immune } \\
\text { response }\end{array}$ & $\begin{array}{l}\text { Presentation of vaccine antigens to other cell types in } \\
\text { the immune system } \\
\text { High levels of both HLA subtypes and costimulatory } \\
\text { molecules are expressed } \\
\text { Stimulate both naive and memory T cells }\end{array}$ & $\begin{array}{l}\text { Ex-vivo expansion, } \\
\text { maturation and } \\
\text { activation of DC is } \\
\text { technically challenging. } \\
\text { Treatment needs to be } \\
\text { individualised for each } \\
\text { patient }\end{array}$ \\
\hline
\end{tabular}

resistance in individual patients remains a challenge and trials that incorporate biopsies and biomarker analysis will be needed in the new world of personalised cancer therapy. Directing the immune system to eradicate cancer cells is exciting, either by using vaccines or immune checkpoint modulators.

\section{REFERENCES}

Adams CW, Allison DE, Flagella K, Presta L, Clarke J, Dybdal N, McKeever K, Sliwkowski MX (2006) Humanization of a recombinant monoclonal antibody to produce a therapeutic HER dimerization inhibitor, pertuzumab. Cancer Immunol Immunother 55(6): 717-727.

Bachelot T, Romieu G, Campone M, Dieras V, Cropet C, Dalenc F, Jimenez M, Le Rhun E, Pierga JY, Goncalves A, Leheurteur M, Domont J, Gutierrez M, Cure H, Ferrero JM, Labbe-Devilliers C (2013) Lapatinib plus capecitabine in patients with previously untreated brain metastases from HER2-positive metastatic breast cancer (LANDSCAPE): a singlegroup phase 2 study. Lancet Oncol 14(1): 64-71.

Baselga J, Bradbury I, Eidtmann H, Di Cosimo S, de Azambuja E, Aura C, Gomez H, Dinh P, Fauria K, Van Dooren V, Aktan G, Goldhirsch A, Chang TW, Horvath Z, Coccia-Portugal M, Domont J, Tseng LM, Kunz G, Sohn JH, Semiglazov V, Lerzo G, Palacova M, Probachai V, Pusztai L, Untch M, Gelber RD, Piccart-Gebhart M (2012a) Lapatinib with trastuzumab for HER2-positive early breast cancer (NeoALTTO): a randomised, open-label, multicentre, phase 3 trial. Lancet 379(9816): 633-640.

Baselga , Campone M, Piccart M, Burris 3rd HA, Rugo HS, Sahmoud T, Noguchi S, Gnant M, Pritchard KI, Lebrun F, Beck JT, Ito Y, Yardley D, Deleu I, Perez A, Bachelot T, Vittori L, Xu Z, Mukhopadhyay P,
Lebwohl D, Hortobagyi GN (2012b) Everolimus in postmenopausal hormone-receptor-positive advanced breast cancer. N Engl J Med 366(6): 520-529.

Baselga J, Cortes J, Kim SB, Im SA, Hegg R, Im YH, Roman L, Pedrini JL, Pienkowski T, Knott A, Clark E, Benyunes MC, Ross G, Swain SM (2012c) Pertuzumab plus trastuzumab plus docetaxel for metastatic breast cancer. $N$ Engl J Med 366(2): 109-119.

Berns K, Horlings HM, Hennessy BT, Madiredjo M, Hijmans EM, Beelen K, Linn SC, Gonzalez-Angulo AM, Stemke-Hale K, Hauptmann M, Beijersbergen RL, Mills GB, van de Vijver MJ, Bernards R (2007) A functional genetic approach identifies the PI3K pathway as a major determinant of trastuzumab resistance in breast cancer. Cancer Cell 12(4): 395-402.

Blackwell KL, Burstein HJ, Storniolo AM, Rugo H, Sledge G, Koehler M, Ellis C, Casey M, Vukelja S, Bischoff J, Baselga J, O’Shaughnessy J (2010) Randomized study of Lapatinib alone or in combination with trastuzumab in women with ErbB2-positive, trastuzumab-refractory metastatic breast cancer. J Clin Oncol 28(7): 1124-1130.

Burstein HJ, Keshaviah A, Baron AD, Hart RD, Lambert-Falls R, Marcom PK, Gelman R, Winer EP (2007) Trastuzumab plus vinorelbine or taxane chemotherapy for HER2-overexpressing metastatic breast cancer: the trastuzumab and vinorelbine or taxane study. Cancer 110(5): 965-972.

Chandarlapaty S, Sakr RA, Giri D, Patil S, Heguy A, Morrow M, Modi S, Norton L, Rosen N, Hudis C, King TA (2012) Frequent mutational activation of the PI3K-AKT pathway in trastuzumab-resistant breast cancer. Clin Cancer Res 18(24): 6784-6791.

Cortes J, Fumoleau P, Bianchi GV, Petrella TM, Gelmon K, Pivot X, Verma S, Albanell J, Conte P, Lluch A, Salvagni S, Servent V, Gianni L, Scaltriti M, Ross GA, Dixon J, Szado T, Baselga J (2012) Pertuzumab monotherapy after trastuzumab-based treatment and subsequent reintroduction of 
trastuzumab: activity and tolerability in patients with advanced human epidermal growth factor receptor 2-positive breast cancer. J Clin Oncol 30(14): 1594-1600.

DeLong ER, DeLong DM, Clarke-Pearson DL (1988) Comparing the areas under two or more correlated receiver operating characteristic curves: a nonparametric approach. Biometrics 44(3): 837-845.

Esteva FJ (2004) Monoclonal antibodies, small molecules, and vaccines in the treatment of breast cancer. Oncologist 9: 4-9.

Esteva FJ, Guo H, Zhang S, Santa-Maria C, Stone S, Lanchbury JS, Sahin AA, Hortobagyi GN, Yu D (2010) PTEN, PIK3CA, p-AKT, and p-p70S6K status: association with trastuzumab response and survival in patients with HER2-positive metastatic breast cancer. Am J Pathol 177(4): $1647-1656$.

Esteva FJ, Valero V, Booser D, Guerra LT, Murray JL, Pusztai L, Cristofanilli M, Arun B, Esmaeli B, Fritsche HA, Sneige N, Smith TL, Hortobagyi GN (2002) Phase II study of weekly docetaxel and trastuzumab for patients with HER-2-overexpressing metastatic breast cancer. J Clin Oncol 20(7): 1800-1808.

Geyer CE, Forster J, Lindquist D, Chan S, Romieu CG, Pienkowski T, Jagiello-Gruszfeld A, Crown J, Chan A, Kaufman B, Skarlos D, Campone M, Davidson N, Berger M, Oliva C, Rubin SD, Stein S, Cameron D (2006) Lapatinib plus capecitabine for HER2-positive advanced breast cancer. N Engl J Med 355(26): 2733-2743.

Gianni L, Pienkowski T, Im YH, Roman L, Tseng LM, Liu MC, Lluch A, Staroslawska E, de la Haba-Rodriguez J, Im SA, Pedrini JL, Poirier B, Morandi P, Semiglazov V, Srimuninnimit V, Bianchi G, Szado T, Ratnayake J, Ross G, Valagussa P (2012) Efficacy and safety of neoadjuvant pertuzumab and trastuzumab in women with locally advanced, inflammatory, or early HER2-positive breast cancer (NeoSphere): a randomised multicentre, open-label, phase 2 trial. Lancet Oncol 13(1): 25-32.

Gianni L, Romieu GH, Lichinitser M, Serrano SV, Mansutti M, Pivot X, Mariani P, Andre F, Chan A, Lipatov O, Chan S, Wardley A, Greil R, Moore N, Prot S, Pallaud C, Semiglazov V (2013) AVEREL: a randomized phase III trial evaluating bevacizumab in combination with docetaxel and trastuzumab as first-line therapy for HER2-positive locally recurrent/ metastatic breast cancer. J Clin Oncol 31(14): 1719-1725.

Inoue S, Ding H, Portilla-Arias J, Hu J, Konda B, Fujita M, Espinoza A, Suhane S, Riley M, Gates M, Patil R, Penichet ML, Ljubimov AV, Black KL, Holler E, Ljubimova JY (2011) Polymalic acid-based nanobiopolymer provides efficient systemic breast cancer treatment by inhibiting both HER2/neu receptor synthesis and activity. Cancer Res 71(4): 1454-1464.

Jerusalem G, Andre F, Chen D, Robinson D, Ozguroglu M, Lang I, White M, Toi M, Taran T, Gianni L (2013) Evaluation of everolimus (EVE) in HER2 + advanced breast cancer (BC) with activated PI3K/mTOR pathway: exploratory biomarker observations from the BOLERO-3 trial. Eur $J$ Cancer 49(Suppl 3): PS8.

Jhaveri K, Esteva FJ (2014) Pertuzumab in the treatment of HER2 + breast cancer. J Natl Compr Canc Netw 12(4): 591-598.

Jhaveri K, Ochiana SO, Dunphy MP, Gerecitano JF, Corben AD, Peter RI, Janjigian YY, Gomes-Dagama EM, Koren 3rd J, Modi S, Chiosis G (2014) Heat shock protein 90 inhibitors in the treatment of cancer: current status and future directions. Expert Opin Investig Drugs 23(5): 611-628.

Johnston S, Pippen Jr J, Pivot X, Lichinitser M, Sadeghi S, Dieras V, Gomez HL, Romieu G, Manikhas A, Kennedy MJ, Press MF, Maltzman J, Florance A, O’Rourke L, Oliva C, Stein S, Pegram M (2009) Lapatinib combined with letrozole versus letrozole and placebo as first-line therapy for postmenopausal hormone receptor-positive metastatic breast cancer. J Clin Oncol 27(33): 5538-5546.

Kaufman B, Mackey JR, Clemens MR, Bapsy PP, Vaid A, Wardley A, Tjulandin S, Jahn M, Lehle M, Feyereislova A, Revil C, Jones A (2009) Trastuzumab plus anastrozole versus anastrozole alone for the treatment of postmenopausal women with human epidermal growth factor receptor 2-positive, hormone receptor-positive metastatic breast cancer: results from the randomized phase III TAnDEM study. J Clin Oncol 27(33): 5529-5537.

King CR, Kraus MH, Aaronson SA (1985) Amplification of a novel $\mathrm{v}$-erbB-related gene in a human mammary carcinoma. Science 229(4717): 974-976.

Krop IE, LoRusso P, Miller KD, Modi S, Yardley D, Rodriguez G, Guardino E, Lu M, Zheng M, Girish S, Amler L, Winer EP, Rugo HS (2012) A phase II study of trastuzumab emtansine in patients with human epidermal growth factor receptor 2-positive metastatic breast cancer who were previously treated with trastuzumab, lapatinib, an anthracycline, a taxane, and capecitabine. J Clin Oncol 30(26): 3234-3241.

Lee-Hoeflich ST, Crocker L, Yao E, Pham T, Munroe X, Hoeflich KP, Sliwkowski MX, Stern HM (2008) A central role for HER3 in HER2amplified breast cancer: implications for targeted therapy. Cancer Res 68(14): 5878-5887.

Lin NU, Winer EP, Wheatley D, Carey LA, Houston S, Mendelson D, Munster P, Frakes L, Kelly S, Garcia AA, Cleator S, Uttenreuther-Fischer M, Jones H, Wind S, Vinisko R, Hickish T (2012) A phase II study of afatinib (BIBW 2992), an irreversible ErbB family blocker, in patients with HER2positive metastatic breast cancer progressing after trastuzumab. Breast Cancer Res Treat 133(3): 1057-1065.

Loi S, Sirtaine N, Piette F, Salgado R, Viale G, Van Eenoo F, Rouas G, Francis P, Crown JP, Hitre E, de Azambuja E, Quinaux E, Di Leo A, Michiels S, Piccart MJ, Sotiriou C (2013) Prognostic and predictive value of tumour-infiltrating lymphocytes in a phase III randomized adjuvant breast cancer trial in node-positive breast cancer comparing the addition of docetaxel to doxorubicin with doxorubicin-based chemotherapy: BIG 02-98. J Clin Oncol 31(7): 860-867.

Lu CH, Wyszomierski SL, Tseng LM, Sun MH, Lan KH, Neal CL, Mills GB, Hortobagyi GN, Esteva FJ, Yu D (2007) Preclinical testing of clinically applicable strategies for overcoming trastuzumab resistance caused by PTEN deficiency. Clin Cancer Res 13(19): 5883-5888.

Marty M, Cognetti F, Maraninchi D, Snyder R, Mauriac L, Tubiana-Hulin M, Chan S, Grimes D, Anton A, Lluch A, Kennedy J, O’Byrne K, Conte P, Green M, Ward C, Mayne K, Extra JM (2005) Randomized phase II trial of the efficacy and safety of trastuzumab combined with docetaxel in patients with human epidermal growth factor receptor 2-positive metastatic breast cancer administered as first-line treatment: the M77001 study group. J Clin Oncol 23(19): 4265-4274.

Morrow PK, Wulf GM, Ensor J, Booser DJ, Moore JA, Flores PR, Xiong Y, Zhang S, Krop IE, Winer EP, Kindelberger DW, Coviello J, Sahin AA, Nunez R, Hortobagyi GN, Yu D, Esteva FJ (2011) Phase I/II study of trastuzumab in combination with everolimus (RAD001) in patients with HER2-overexpressing metastatic breast cancer who progressed on trastuzumab-based therapy. J Clin Oncol 29(23): 3126-3132.

Murthy RK, Varma A, Mishra P, Hess KR, Young E, Murray JL, Koenig KH, Moulder SL, Melhem-Bertrandt A, Giordano SH, Booser D, Valero V, Hortobagyi GN, Esteva FJ (2014) Effect of adjuvant/neoadjuvant trastuzumab on clinical outcomes in patients with HER2-positive metastatic breast cancer. Cancer 120: 1932-1938.

Nagata Y, Lan KH, Zhou X, Tan M, Esteva FJ, Sahin AA, Klos KS, Li P, Monia BP, Nguyen NT, Hortobagyi GN, Hung MC, Yu D (2004) PTEN activation contributes to tumour inhibition by trastuzumab, and loss of PTEN predicts trastuzumab resistance in patients. Cancer Cell 6(2): 117-127.

Nahta R, Hung MC, Esteva FJ (2004) The HER-2-targeting antibodies trastuzumab and pertuzumab synergistically inhibit the survival of breast cancer cells. Cancer Res 64(7): 2343-2346.

Nahta R, Yu D, Hung MC, Hortobagyi GN, Esteva FJ (2006) Mechanisms of disease: understanding resistance to HER2-targeted therapy in human breast cancer. Nat Clin Pract Oncol 3(5): 269-280.

Nahta R, Yuan LX, Zhang B, Kobayashi R, Esteva FJ (2005) Insulin-like growth factor-I receptor/human epidermal growth factor receptor 2 heterodimerization contributes to trastuzumab resistance of breast cancer cells. Cancer Res 65(23): 11118-11128.

Peoples GE, Gurney JM, Hueman MT, Woll MM, Ryan GB, Storrer CE, Fisher C, Shriver CD, Ioannides CG, Ponniah S (2005) Clinical trial results of a HER2/neu (E75) vaccine to prevent recurrence in high-risk breast cancer patients. J Clin Oncol 23(30): 7536-7545.

Perou CM, Sorlie T, Eisen MB, van de RM, Jeffrey SS, Rees CA, Pollack JR, Ross DT, Johnsen H, Akslen LA, Fluge O, Pergamenschikov A, Williams C, Zhu SX, Lonning PE, Borresen-Dale AL, Brown PO, Botstein D (2000) Molecular portraits of human breast tumours. Nature 406(6797): 747-752.

Robert N, Leyland-Jones B, Asmar L, Belt R, Ilegbodu D, Loesch D, Raju R, Valentine E, Sayre R, Cobleigh M, Albain K, McCullough C, Fuchs L, Slamon D (2006) Randomized phase III study of trastuzumab, paclitaxel, and carboplatin compared with trastuzumab and paclitaxel in women with HER-2-overexpressing metastatic breast cancer. J Clin Oncol 24(18): $2786-2792$. 
Salazar LG, Goodell V, O’meara M, Knutson KL, Dang Y, dela Rosa C, Gutherie KA, Disis ML (2009) Persistent immunity and survival after immunization with a HER2/neu (HER2) vaccine. ASCO Meeting Abstr 27(15S): 3010.

Schechter AL, Hung MC, Vaidyanathan L, Weinberg RA, Yang-Feng TL, Francke U, Ullrich A, Coussens L (1985) The neu gene: an erbBhomologous gene distinct from and unlinked to the gene encoding the EGF receptor. Science 229(4717): 976-978.

Schneeweiss A, Chia S, Hickish T, Harvey V, Eniu A, Hegg R, Tausch C, Seo JH, Tsai YF, Ratnayake J, McNally V, Ross G, Cortes J (2013) Pertuzumab plus trastuzumab in combination with standard neoadjuvant anthracycline-containing and anthracycline-free chemotherapy regimens in patients with HER2-positive early breast cancer: a randomized phase II cardiac safety study (TRYPHAENA). Ann Oncol 24(9): 2278-2284.

Seidman AD, Fornier M, Esteva FJ, Tan L, Kaptain S, Bach A, Panageas KS, Arroyo C, Valero V, Currie V, Gilewski T, Theodoulou M, Moynahan ME, Moasser M, Sklarin N, Dickler M, D'Andrea G, Cristofanilli M, Rivera E, Hortobagyi GN, Norton L, Hudis C (2001) Weekly trastuzumab and paclitaxel therapy for metastatic breast cancer with analysis of efficacy by HER2 immunophenotype and gene amplification. J Clin Oncol 19(10): 2587-2595.

Slamon DJ, Clark GM, Wong SG, Levin WJ, Ullrich A, McGuire WL (1987) Human breast cancer: correlation of relapse and survival with amplification of the HER-2/neu oncogene. Science 235(4785): 177-182.

Slamon DJ, Leyland-Jones B, Shak S, Fuchs H, Paton V, Bajamonde A, Fleming T, Eiermann W, Wolter J, Pegram M, Baselga J, Norton L (2001) Use of chemotherapy plus a monoclonal antibody against HER2 for metastatic breast cancer that overexpresses HER2. N Engl J Med 344(11): 783-792.

Stagg J, Loi S, Divisekera U, Ngiow SF, Duret H, Yagita H, Teng MW, Smyth MJ (2011) Anti-ErbB-2 mAb therapy requires type I and II interferons and synergizes with anti-PD-1 or anti-CD137 mAb therapy. Proc Natl Acad Sci USA 108(17): 7142-7147.

TCGA-Network (2012) Comprehensive molecular portraits of human breast tumours. Nature 490(7418): 61-70.

Untch M, Loibl S, Bischoff J, Eidtmann H, Kaufmann M, Blohmer JU, Hilfrich J, Strumberg D, Fasching PA, Kreienberg R, Tesch H, Hanusch C, Gerber B, Rezai M, Jackisch C, Huober J, Kuhn T, Nekljudova V, von Minckwitz G (2012) Lapatinib versus trastuzumab in combination with neoadjuvant anthracycline-taxane-based chemotherapy (GeparQuinto, GBG 44): a randomised phase 3 trial. Lancet Oncol 13(2): 135-144.

Valero V, Forbes J, Pegram MD, Pienkowski T, Eiermann W, von Minckwitz G, Roche H, Martin M, Crown J, Mackey JR, Fumoleau P, Rolski J, Mrsic-Krmpotic Z, Jagiello-Gruszfeld A, Riva A, Buyse M, Taupin H, Sauter G, Press MF, Slamon DJ (2011) Multicenter phase III randomized trial comparing docetaxel and trastuzumab with docetaxel, carboplatin, and trastuzumab as first-line chemotherapy for patients with HER2-geneamplified metastatic breast cancer (BCIRG 007 study): two highly active therapeutic regimens. J Clin Oncol 29(2): 149-156.

Verma S, Miles D, Gianni L, Krop IE, Welslau M, Baselga J, Pegram M, Oh DY, Dieras V, Guardino E, Fang L, Lu MW, Olsen S, Blackwell K (2012) Trastuzumab emtansine for HER2-positive advanced breast cancer. $N$ Engl J Med 367(19): 1783-1791.

von Minckwitz G, du Bois A, Schmidt M, Maass N, Cufer T, de Jongh FE, Maartense E, Zielinski C, Kaufmann M, Bauer W, Baumann KH, Clemens MR, Duerr R, Uleer C, Andersson M, Stein RC, Nekljudova V, Loibl S (2009) Trastuzumab beyond progression in human epidermal growth factor receptor 2-positive advanced breast cancer: a german breast group 26/breast international group 03-05 study. J Clin Oncol 27(12): $1999-2006$.

Wolff AC, Hammond ME, Hicks DG, Dowsett M, McShane LM, Allison KH, Allred DC, Bartlett JM, Bilous M, Fitzgibbons P, Hanna W, Jenkins RB, Mangu PB, Paik S, Perez EA, Press MF, Spears PA, Vance GH, Viale G, Hayes DF. American Society of Clinical O, College of American P (2013) Recommendations for human epidermal growth factor receptor 2 testing in breast cancer: American Society of Clinical Oncology/College of American Pathologists clinical practice guideline update. J Clin Oncol 31(31): 3997-4013.

Zhang S, Huang WC, Li P, Guo H, Poh SB, Brady SW, Xiong Y, Tseng LM, Li SH, Ding Z, Sahin AA, Esteva FJ, Hortobagyi GN, Yu D (2011) Combating trastuzumab resistance by targeting SRC, a common node downstream of multiple resistance pathways. Nat Med 17(4): 461-469.

(c) (i) (2) (2) This work is licensed under the Creative Commons (c) ${ }_{\mathrm{BY}} \mathrm{NC}$ SA Attribution-NonCommercial-Share Alike 3.0 Unported License. To view a copy of this license, visit http://creativecommons. org/licenses/by-nc-sa/3.0/ 